\title{
Stygobitic invertebrates in groundwater - a review from a hydrogeological perspective
}

\author{
Lou Maurice and John Bloomfield
}

\begin{abstract}
Groundwater-adapted species (known as stygobites) provide an important contribution to biodiversity. Groundwater ecosystems are some of the oldest on earth, and contain many endemic species adapted to live in an environment with no light and limited resources. The controls on stygobite distributions are not yet fully resolved because of the complex interaction between many processes operating at different scales. Many of these processes are geological or hydrogeological in nature and therefore more detailed geological and hydrogeological studies could provide improved understanding of stygobite distributions. Hydrogeologists can assist ecologists by providing expertise on both general geological characteristics of sampling sites, and how groundwater at sampling sites relates to the wider aquifer setting. Geological input would be especially useful in stygobite dispersal studies because dispersal depends upon habitat continuity associated with geological dispersal corridors, and is limited where rocks that do not provide a suitable habitat form geological barriers. Stygobite studies are of benefit to hydrogeology because stygobite distributions can provide information on groundwater-surface water interaction and aquifer connectivity over a range of spatio-temporal scales. Future studies using DNA analysis of stygobites may provide much more detailed information on hydraulic connectivity within and between aquifers. There is also potential for the development of stygobites as indicators of groundwater quality. The biogeochemical function of stygobites is of interest to both hydrogeologists and ecologists. Studies have demonstrated that stygobites graze biofilms and bacteria but their role in biogeochemical cycles is still not fully understood. Ecosystem services provided by groundwater fauna depend upon their abundance and biomass. Future studies using hydrogeological data (e.g. borehole packer techniques) may provide an improved understanding of where in aquifers stygobites live and how many there are which might be an important step towards assessing the significance of their role in biogeochemical cycling of nutrients and carbon.
\end{abstract}

\section{Introduction}

The term 'groundwater' encompasses all water beneath the surface within rocks and sediments. Micro-organisms occur in most groundwater environments and in many groundwaters meiofauna and macroinvertebrates are also present. Animals that live their whole life cycle in groundwater and that generally do not exist in surface waters are known as stygobites (Gibert et al., 1994). Stygobites are thought to provide a range of ecosystem services as a consequence of the role they contribute to biogeochemical cycling and maintaining water quality via their interactions with the microbial community. They may also be useful as markers of good qualitative status of groundwater (Tomlinson and Boulton, 2010), and are scientifically important because they are an unusual example of an ancient fauna that have survived periods of geological and climate change (Humphreys, 2001, 2009; Hänfling et al., 2009). However, in many areas of the world groundwater communities remain poorly studied and the full extent of biodiversity remains unknown. Several authors have highlighted the interdisciplinary nature of groundwater ecology and the need for 
collaboration between ecologists, biologists and hydrogeologists (e.g.Gibert et al., 1994; Hancock et al., 2005; Humphreys 2009; Steube et al., 2009). However, there appear to be few examples where hydrogeologists have contributed substantially to groundwater ecology studies. This may be because these are normally carried out by ecologists, and groundwater ecology is generally seen of low importance in hydrogeology. For hydrogeologists the major concerns are developing quantitatively sustainable groundwater supplies, managing impacts of groundwater abstraction on surface watercourses and their associated ecosystems, and managing groundwater contamination. Hydrogeologists commonly have little knowledge of groundwater ecosystems and would not consider stygobites to be relevant to hydrogeological investigations. There have been many reviews of groundwater ecosystems that have largely been presented from an ecological viewpoint (e.g. Hancock et al., 2005; Danielopol and Griebler, 2008; Tomlinson and Boulton, 2010). This paper will first introduce the disciplines of hydrogeology and groundwater ecology to those unfamiliar with these specialisations. The main aim of the paper is to discuss the role of a hydrogeological perspective in groundwater ecology studies, and to consider the value of groundwater ecosystems to hydrogeologists. Additionally, unresolved questions offering scope for new interdisciplinary studies are highlighted. Although we will make passing reference to micro-organisms, the focus will be on macroscopic stygobites (generally $>40$ $\mu \mathrm{m})$.

\section{Background:}

\section{$\underline{2.1 \text { Introduction to hydrogeology }}$}

Hydrogeology is the study of the chemical and physical characteristics of groundwater. Groundwater can be stored in, or transmitted through, different types of voids in rocks, which form a habitat for organisms. It is widely recognised that groundwater ecosystems are influenced by the permeability characteristics of rocks. Permeability is a measure of the intrinsic property of rocks to transmit fluids. Hydraulic conductivity is the ability of rocks to transmit water and is dependent on permeability and on fluid properties. Transmissivity is the product of the hydraulic conductivity and a saturated thickness. Measures of hydraulic conductivity and transmissivity can be obtained from testing boreholes drilled into the rock. Interpreting hydraulic conductivity and transmissivity data requires care because results may vary depending upon the type and duration of the test, and the analytical solution used.

Simple hydrogeological classifications can be applied to rocks based on permeability characteristics and void structure (Fig. 1). Impermeable rocks in which almost no water is transmitted are known as aquicludes, whilst aquitards have relatively low permeability and only limited water flow is possible. It is likely that aquicludes (and perhaps aquitards) may not provide a suitable habitat for many invertebrates and may form barriers to the dispersal of many species. Permeable rocks that store and transmit relatively large quantities of water are known as aquifers, and these are usually good habitats for fauna. They may be simply classified into granular aquifers (also known as porous aquifers) in which water is stored and transmitted in pores between sand and gravel grains, fractured aquifers in which water moves through fractures within the rock, and karst aquifers in which fractures are enlarged by dissolutional processes to form larger voids. These may be fissures (fractures enlarged by dissolution which retain the broadly planar geometry of unmodified fractures), conduits 
(tubular or sometimes rectangular shaped voids), and caves (conduits large enough for humans to enter).

Hydrogeological classifications of rock types have been applied to many studies of groundwater fauna (e.g. Gibert et al. 1994; Dole-Olivier et al., 2009a; Hahn and Fuchs 2009). However, there is a degree of subjectivity in the classification of aquicludes, aquitards and aquifers. Without hydrogeological investigation, it may be unclear whether a low permeability rock is functioning as an aquiclude or an aquitard. Fractured rocks may function as aquicludes, aquitards or aquifers depending upon the density and connectivity of fractures. The classification of aquifers as porous, fractured or karstic is a simplification, as aquifers may fall into more than one category. For example, mixed porous and fractured aquifers are common where rocks have locally variable degrees of consolidation (e.g. some sandstones) or locally variable degrees of weathering (e.g. granite). Karst aquifers encompass a wide range of rocks that are often, but not always, composed of calcium carbonate. These exhibit varying degrees of karstification. At the lower end of the karstification scale, caves may be generally absent but dissolutional enlargement of fractures to form fissures and small conduits may be widespread. Such aquifers could be classified as fractured or karstic. In highly karstic aquifers, caves are common, although there are also networks of smaller solutional voids. Groundwater therefore provides a wide range of habitats for fauna (bold text in Fig. 1), within which there may be various local physical habitats (italic text in Fig. 1). Groundwater fauna are sampled from different types of habitats that have distinctive faunal assemblages: springs, the hyporheic zone (groundwater in sediments immediately below rivers), caves, and boreholes drilled into the rock.

Figure 1: Simplified hydrogeological classification showing broad habitat categories (bold) and their physical components (italics)

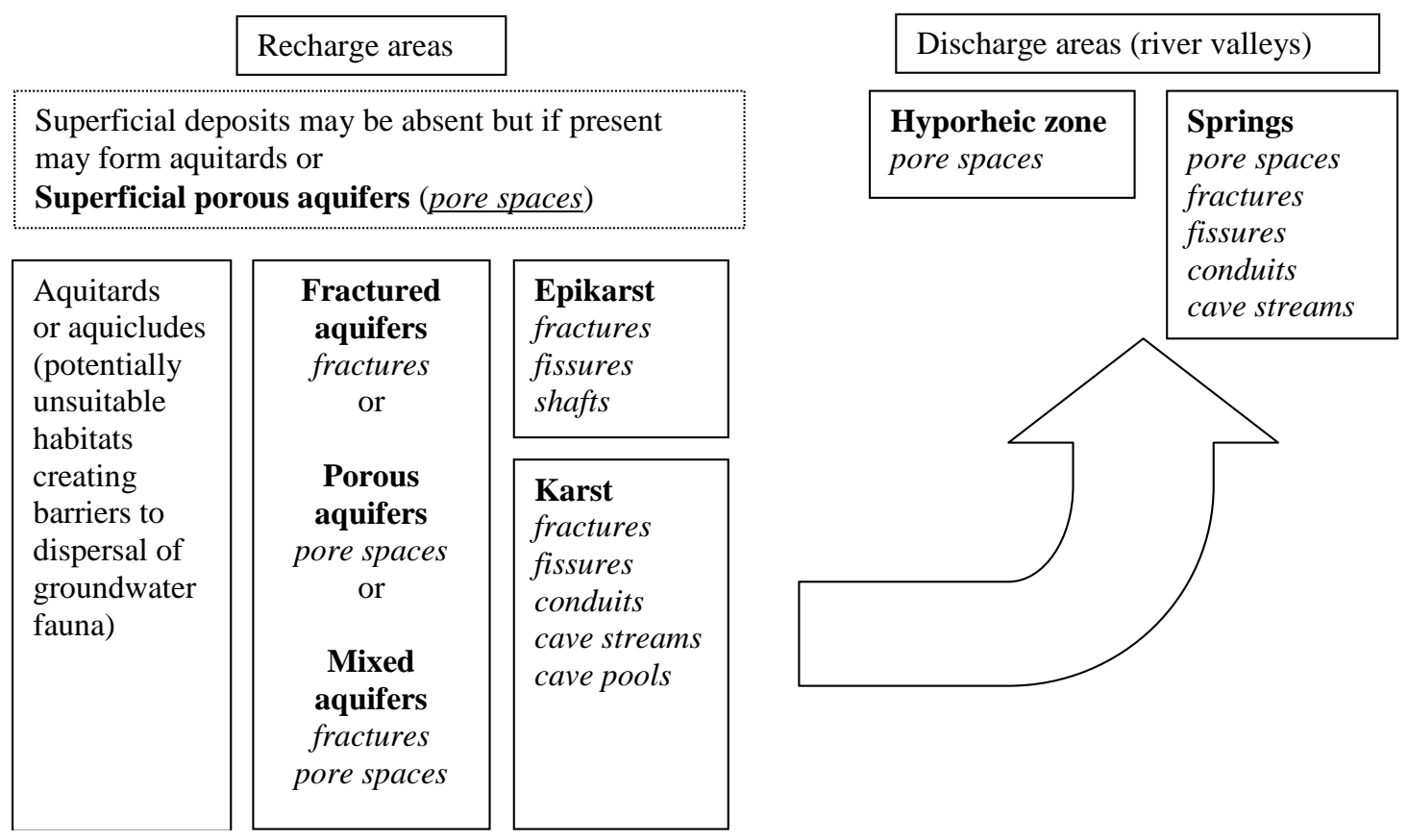




\subsection{Stygobites: an important contribution to biodiversity}

Stygobites are adapted to inhabit the subsurface environment in which there is no light and resources may be sparse (Gibert et al., 1994; Humphreys, 2009). These adaptations generally include reduction or total loss of eyes resulting in blindness, evolution of long sensory appendages enabling movement in the dark, and elongation of body shape enabling passage through small voids (Gibert et al., 1994). Stygobites lack pigmentation, are colourless and often translucent (Fig. 2). They are thought to be slow-growing, long-lived, and to have few young compared to surface water invertebrates (Gibert et al., 1994; Humphreys, 2009). They live in voids within rocks ranging in scale from pore spaces between grains in porous aquifers, to fractures in the rock, to larger dissolutional voids in karst aquifers, to pools and underground streams in large caves. Stygobites exhibit a range of trophic strategies from grazing of bacterial and fungal biofilms to predation of other invertebrates (Gibert et al., 1994). Other organisms that usually live above ground but can also exploit resources in groundwater are called Stygophiles, while Stygoxenes are organisms that occur only accidentally in groundwater environments (Gibert et al., 1994).

\section{Figure 2: UK stygobite Niphargus aquilex ( 15 mm long)}

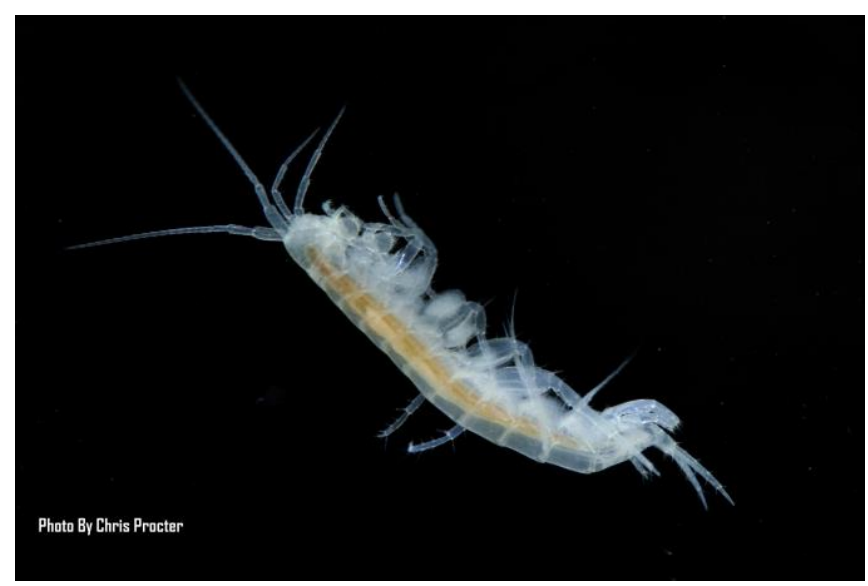

The larger stygobitic invertebrate species come from several different taxonomic groups of animals. Many are crustaceans from the classes Branchiopoda, Ostracoda, Copepoda and Malacostraca. Within the Branchiopoda class there are species of Cladocera (water fleas). Within the Malacostraca class there are species from the Amphipoda, Isopoda and Syncarida orders. Other groundwater species include Oligochaeta and Hirudinea species from the Phylum Annelida (worms); Hydracarina (water mites); Mollusca (snails and slugs); and Nematoda (roundworms).

Recognition of the diversity of organisms in groundwater has increased during the last 30 years (Sket, 1999; Gibert and Culver, 2009), and stygobites have been shown to provide an important contribution to biodiversity (Boulton et al., 2008). Botosaneanu (1986) reported 6634 stygobite species, and Gibert and Culver (2004) noted that 7700 were known in 2000. Danielopol et al. (2000) reported that in Europe, stygobites constitute about $40 \%$ of all 
freshwater crustacean species, implying an important role in crustacean diversity. It is widely recognised that high levels of endemism and low levels of sampling mean that the currently known species are likely to constitute only a small proportion of the actual diversity in groundwater (Danielopol et al., 2000; Gibert and Deharveng, 2002). Studies in Australia over the last 10 years confirm this, illustrating high diversity, new species and endemism over small areas (e.g. Tomlinson and Boulton, 2008; Eberhard et al., 2009; Humphries et al., 2009;). Surveys in Western Australia found a new genus of isopod, more than 70 new species of copepods, and over 110 new species of ostracods (Tomlinson and Boulton, 2008). During a recent European study more than 100 new stygobite species were identified (Gibert et al., 2009).

It is thought that there are also many cryptic species that have not yet been identified (Gibert and Culver, 2009) and most studies that have investigated cryptic diversity using genetic techniques have found new species, often with ranges of less than $200 \mathrm{~km}^{2}$ (e.g. Lefébure et al., 2006; Trontelj et al., 2009; Bradford et al., 2010; Flot et al., 2010).

The high degree of specialisation, adaptation and endemism make groundwater animals of particular importance to biologists working on fundamental questions of evolution, ecology, biodiversity and physiology (Danielopol et al., 2000). Some groundwater ecosystems are chemoautotrophic with the micro-organisms at the base of the food chain deriving their energy from another electron receptor such as sulphur rather than oxygen (Gibert and Deharveng, 2002; Humphreys, 2009; Porter et al., 2009). For example chemoautotrophic ecosystems have been found in caves in Europe, Israel and the United States; and in the Edwards Aquifer in Texas (Gibert and Deharveng, 2002; Engel et al., 2004; Porter et al., 2009; Flot et al., 2010). These unusual ecosystems are thought to function in a similar manner to those associated with deep ocean vents.

Several studies have emphasised the need for ecological assessments of groundwater in addition to current assessments of groundwater quality and quantity (e.g. Malard et al., 2007; Tomlinson et al., 2007; Steube et al., 2009; Griebler et al., 2010; Korbel and Hose, 2011). The important contribution of groundwater ecosystems to global biodiversity has been recognised in some countries. In the USA, groundwater species are protected under wildlife laws (Humphreys, 2009). In Australia, legislation requires the potential impacts of human activities on groundwater ecosystems to be assessed and monitored (NSW Department of Land and Water Conservation, 2002; Environmental Protection Agency, 2003; Hancock and Boulton, 2009). In Switzerland, the 1998 Swiss Water Protection Ordinance includes the ecological quality of groundwater (Griebler et al., 2010). Owing to the current lack of knowledge about the distribution of groundwater fauna and the ecosystem services they provide, the current EU groundwater directive (2006/118/EC) calls for further research to provide better criteria for ensuring groundwater ecosystem quality and protection, and states 'Where necessary, the findings obtained should be taken into account when implementing or revising this directive. Such research, as well as dissemination of knowledge, experience and research findings, needs to be encouraged and funded'. 


\section{The role of stygobites in hydrogeological and geological studies}

\subsection{Aquifer characterisation}

A common requirement of hydrogeological investigations is aquifer characterisation. This entails understanding the spatial distributions of water flow and storage, and how these vary through time. Studies of aquifer properties (permeability, transmissivity, storage), fracture distributions, flow in the unsaturated and saturated zones, springs, and tracer tests may all contribute to aquifer characterisation. These investigations are used to develop conceptual models of how aquifers function and where groundwater bodies are connected together. Aquifer characterisation and the development of a good conceptual model are essential to groundwater modelling which is used to investigate flow and contaminant transport processes to ensure successful and sustainable development of water resources.

The structure of groundwater communities can help characterise aquifers by indicating the extent of hydraulic connectivity within aquifers, and the degree of hydraulic connectivity between a part of an aquifer and surface waters (e.g. Dole-Olivier and Marmonier, 1992; Arietti and Edwards, 2006; Hahn, 2006; Bork et al., 2009). Groundwater investigations may involve assessing whether groundwaters contain a low residence time surface water component, because such groundwaters may be vulnerable to contamination. Groundwater ecology studies may assist with this. For example, Hahn (2006) proposed a groundwaterfauna index of the amount of hydrological exchange between surface water and groundwater. Groundwaters with a high degree of exchange with surface waters were identified as those with high levels of oxygen and detritus and a high variability in temperature. These groundwaters have a higher diversity and abundance of stygobites, and also higher proportions of non stygobites (stygoxenes and stygophiles). The groundwater fauna index was tested in South Korea by Bork et al. (2009), who found that whilst hydrochemistry primarily reflected the hydrogeological origin of the waters (alluvial or bedrock), variability in faunal communities reflected the degree of surface watergroundwater interaction. Understanding surface water-groundwater interaction involves multiple strands of evidence and stygobite data are useful in conjunction with water chemistry and microbiological data to build up a complete picture of groundwater systems. Hydrogeologists may also be involved in determining the location of groundwater inputs into surface watercourses using methods such as flow gauging and temperature measurements. The presence of stygobitic fauna in rivers could potentially also be used as evidence of groundwater inputs.

Groundwater ecology studies can provide information on hydraulic connectivity within aquifers or caves. For example, Pipan and Culver (2007) investigated copepods in cave dripwaters. They demonstrated that some copepod species are present within several cave systems whilst others have a limited lateral extent, and some species appear to be restricted to a single dripping source. The implication is that where a species is restricted to a small numbers of cave dripwaters, it is likely that these are hydrologically connected. Such studies do not determine the origin of water within a drip, which would require a tracer test from the surface to the drip. However, it is difficult to carry out tracer tests over large numbers of flowpaths and tracer testing is limited to flowpaths with relatively short travel times (generally less than a month) and low tracer attenuation. In many parts of aquifers, the travel times are too long and/or attenuation too high for tracer testing to be feasible, and measuring chemical 
parameters is the only method of characterising flowpaths with longer residence times. Groundwater fauna distributions may therefore be a useful additional source of information on hydraulic connectivity within aquifers and caves. Locally endemic stygobite species are useful if the species is endemic to a single cave or part of a cave, or to an isolated aquifer (e.g. Humphreys et al., 2009). In this case, all areas of the cave or aquifer where the species is found could be assumed to be hydrologically connected. An area of future development is to use genetic techniques to investigate small-scale genetic variability within stygobite species to aid aquifer characterisation. It is possible that the presence of genetically similar individuals could be used to investigate groundwater catchment areas of springs and boreholes, and hydraulic connectivity within aquifers and between adjacent aquifers.

\subsection{Stygobites as indicators of groundwater quality}

Assuming sufficient void size and connectivity, good quality groundwaters should contain stygobitic invertebrates (Korbel and Hose, 2011), whilst stygobite communities may be absent, depleted, or made up of different species in contaminated groundwaters (e.g. Malard et al., 1994; Wood et al., 2008).

The objective of hydrogeological water quality studies is generally to ensure that abstracted water is of potable quality or, where pollution has occurred, to investigate the potential risk of discharges of polluted groundwater to surface water ecosystems. Contaminant transport in groundwater is complex because most aquifers comprise different components which have highly variable flow rates and residence times. For example, the Chalk is a carbonate aquifer in which contaminants are transported and stored in the porous rock matrix, in fractures, and in karstic dissolutional features. Contaminants move through and between these components via advection, dispersion and diffusion (Foster, 1975; Fretwell et al., 2005; Maurice et al., 2010). Contaminant residence times therefore range from hours to many tens or even hundreds of years. There is added complexity due to variability in recharge which results in temporal variations in flow rates and directions. It may be difficult to determine the location or extent of groundwater contamination, because sampling of the contaminant may not be spatially or temporally comprehensive enough. Stygobites may be useful indicators for assessing groundwater quality because they are a constant feature of the environment and therefore provide a means of integrating the effects of contamination on groundwater quality (Malard et al., 2007; Humphreys, 2009; Steube et al., 2009; Stein et al., 2010). Studies have sought to relate groundwater ecology to anthropogenic pollutants, such as nitrate, in order to identify bioindicators (e.g. Griebler et al., 2010). Stein et al. (2010) investigated two partially separated aquifer systems in the same geological sequence and found that community structure was sensitive to land-use activities that cause elevated nitrate concentrations. However, relationships between groundwater communities and pollutants remain poorly understood. It may be possible to develop methods of using stygobites as sensitive indicators of particular groundwater pollutants, or of good quality groundwaters, but a greater understanding of the relationships between invertebrate stygobite species and both contaminants and micro-organisms is required. 


\subsection{Understanding biogeochemical cycles}

Understanding biogeochemical processes is an important part of hydrogeological investigations of water quality. The role of groundwater ecosystems in biogeochemical cycling and enhancing groundwater quality is not fully understood (Boulton et al., 2008). In particular few studies have directly investigated the role of the larger stygobitic invertebrates ( 1 $\mathrm{mm}$ to $20 \mathrm{~mm}$ in length).

It is thought that feeding, movement and excretion by stygobites and stygophiles can enhance water quality, promote bioremediation, and increase water infiltration (Danielopol, 1989; Hancock et al., 2005; Boulton et al., 2008; Tomlinson and Boulton, 2008; Humphreys, 2009). Movement of larger stygobites has been shown to prevent biofilm clogging and increase permeability in the hyporheic zone (Mermillod-Blondin \& Rosenberg, 2005; Nogaro et al., 2006). Groundwater ecosystem processes accelerate the oxidation of organic matter and therefore may influence redox evolution driving many hydrogeochemical processes (Humphreys, 2009).

The main biogeochemical function of the larger stygobite invertebrates is likely to be via their interactions with the microbial community. Studies have shown that stygobites graze biofilms. For example Hallam et al. (2008) found bacteria in the digestive tract of two stygobite crustacean species in Morocco. Grazing of biofilms by stygobites could prevent biofilm clogging (Boulton et al., 2008; Tomlinson and Boulton, 2010). However, excretion by stygobites can also stimulate bacterial activity, which could promote biodegradation by bacterial communities (Tomlinson and Boulton, 2010). Stygobites can also directly attenuate contaminants. This has been observed in New Zealand where 10 times as many stygobites (mainly crustaceans) were found immediately downstream of an effluent disposal area than in groundwater further downstream or upstream, and gut analysis showed that the stygobites contained coliform bacteria (Boulton et al., 2008). Pacioglu (2009) reports on many studies that have demonstrated increased numbers of invertebrates and/or changes in community structure in hyporheic waters with organic pollution.

Groundwater ecosystems are also thought to provide a means of attenuating high nitrogen from anthropogenic sources in alluvial aquifers, thereby reducing the nitrogen loading of rivers (Tomlinson and Boulton, 2008). Denitrification generally only occurs in anaerobic environments (Rivett et al., 2008). It is therefore likely that microbial communities are more important than larger stygobites for attenuating nitrate because larger invertebrates are less commonly present in anaerobic groundwaters.

\subsection{Palaeohydrogeology}

Palaeohydrogeology is the study of past changes in aquifers and of their long-term evolution, and may provide information on how and when climate and geology have changed. Palaeohydrogeology may also provide information on the historical development of permeability in fractured or karst aquifers, improving understanding of modern-day permeability distributions. 
Groundwater ecosystems can exist unchanged for long periods of geological time. The occurrence of ancient species may provide palaeohydrogeological information on the continued existence of aquifers during ice ages, arid periods and tectonic events (Humphreys 2009). For example, in Iceland species in geothermally heated water survived beneath the Pleistocene ice sheet, demonstrating that during glaciation there can be sufficient water circulation and input of organic matter to sustain a stygobitic community (Bjarni et al., 2007). Humphreys (2001) found that stygobite species have been present for several million years in aquifers below Australian deserts. Humphries et al. (2009) report on the extraordinary endemism of stygobites found in groundwater calcretes (re-deposited limestones) in Western Australia. Each hydrologically isolated calcrete has a unique endemic fauna. For example, molecular studies showed that aquatic beetles speciated between 8 and 5 million years ago (Bradford et al., 2010), suggesting that these calcrete aquifers, which are often only separated by a few hundred metres, have existed for 5-8 million years with no hydrological connectivity between them.

Studies of how groundwaters became colonised and marine or surface water organisms evolved into groundwater organisms may provide insight into the timing of past environmental and geological changes (Notenboom, 1991; Boutin, 1994a). Large-scale climate change could cause the development of a new groundwater species. For example, stygobite studies in Western Australia have found that speciation occurred at a time of aridification during the Tertiary period (Finston et al., 2009). Speciation probably occurred because loss of surface catchments effectively induced local allopatry in subterreanean environments, leading to reduced gene flow and therefore speciation. Studies have also used stygobites to improve knowledge of large-scale biogeographical changes. For example, it was originally thought that the Canary Islands formed around 21-34 million years ago. However, it is now believed that the most ancient parts of the islands are probably $\sim 70$ million years old because the rocks contain stygobites that are thought to have evolved from marine ancestors at this time (Boutin, 1994b).

\section{$\underline{4 \text { The role of hydrogeology and geology in stygobite studies }}$}

\subsection{Geological and hydrogeological controls on stygobite distributions}

It is difficult to assess biodiversity and investigate ecological processes in groundwater because there are many controls on faunal distributions operating over a range of spatial and temporal scales (Hahn, 2009; Stoch and Galassi, 2010). These controls are summarised in Fig. 3. At a regional scale, historical large-scale geological, geomorphological and climatological processes (such as marine transgressions, glaciations, baseflow lowering) may be important in altering the structure of groundwater communities, by causing extinction of some species and isolation or adaptation of others (Malard et al., 2009). At an intermediate scale, the nature of groundwater communities will depend upon whether the rock functions as an aquiclude, aquitard or aquifer, with aquicludes and aquitards potentially creating barriers to the dispersal of invertebrates. Where aquifers are present, the type of aquifer (e.g. porous, karstic or fractured) and general chemical and permeability characteristics will determine the groundwater community. 
Figure 3: Factors controlling observed stygobite distributions

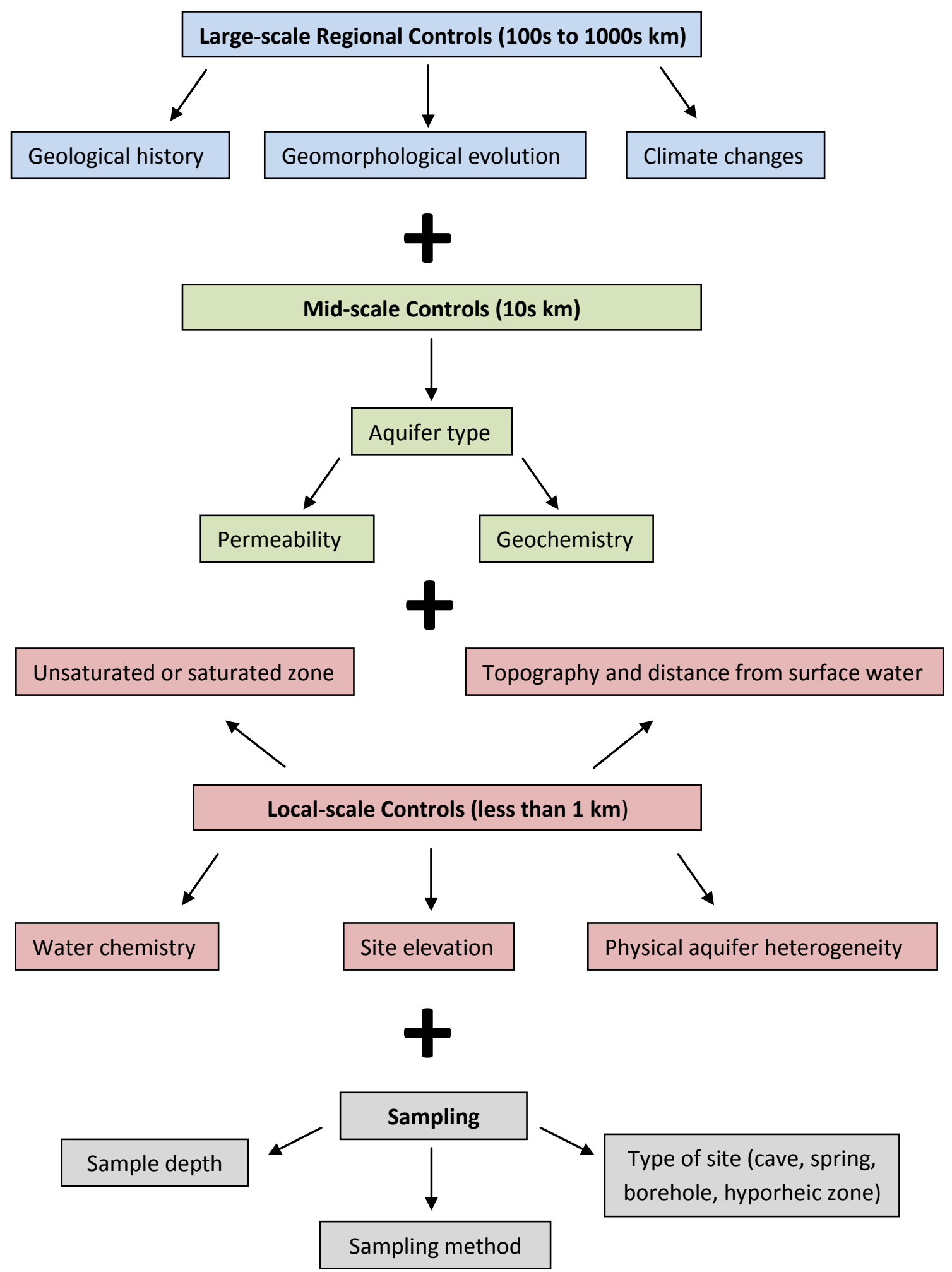

At the local scale groundwater communities are determined by aquifer heterogeneities. Attempting to answer a question related to any of the controls on faunal distributions at any scale is difficult because the fauna present will reflect all these processes and the 
interactions between them: moreover, the relative importance of each process varies from site to site. Additionally, different species are present in the different types of habitat where fauna are sampled (cave, spring, borehole, hyporheic zone). However, as more studies are carried out and global datasets of groundwater fauna grow, the controls on their distributions may become much better defined. Ecological studies that are coupled with improved geological and hydrogeological understanding might be particularly beneficial because geology and hydrogeology are one of the most important influences on species distributions at all scales.

\subsubsection{Large-scale controls on stygobite distributions}

Large-scale long term geological and climate changes have a strong influence on the type and abundance of fauna present in groundwater because stygobite species have much lower dispersal rates than surface water aquatic species (Culver et al., 2009). Summarising data from a study in six European countries (the PASCLIS project), Dole-Olivier et al. (2009a) concluded that in karst areas the main factors influencing biodiversity are regional in scale (factors such as mean latitude, the extent of Pleistocene glaciations and the intensity of karstification).

Glaciation is thought to be a strong control on faunal communities because it causes local extinctions (Hahn and Fuchs, 2009; Malard et al., 2009; Robertson et al., 2009). Species present in areas that have been glaciated either survived in local refugia (e.g. in deep subterranean environments unaffected by permafrost), or are post glacial re-colonisers that have arrived via long distance dispersal (Hahn and Fuchs, 2009). The presence of local endemics can suggest that species have survived glaciations in refugia (e.g. Galassi et al., 2009; Hänfling et al. 2009; Malard et al., 2009)

In Great Britain and Ireland, only 10 stygobitic macrocrustacea have been identified (Proudlove et al., 2003; Robertson et al., 2009), two of which are endemic to Ireland (Niphargus kochianus irlandicus and Niphargus wexfordensis) and one to southeast England (Niphargus glenniei). There have been relatively few groundwater ecology studies and one species, Microniphargus leruthi, was discovered in Ireland only in 2006 (Arnscheidt et al., 2009) and in England in 2010 (Knight and Gledhill, 2010). However, it is unlikely that a substantial number of additional species will be found. Most stygobite records are from areas to the south of the last glacial limit, and it is thought that the low diversity compared to many other areas of the world is due to local extinctions during repeated glaciations (Proudlove et al., 2003; Robertson et al., 2009). However, most stygobite species are also found in South Wales in areas that were covered by the southernmost parts of the icesheet during the most recent glaciation. The amphipod Niphargus aquilex is found in Northern England and the syncarid Anthrobathynella stammeri has the northernmost distribution, having been found in Scotland. All stygobite species found in South Wales or northern areas must either have survived beneath the ice or dispersed to these areas during the last 10000 years (Proudlove et al., 2003). Even if species survived to the south of the glacial front, permafrost or very cold conditions would have been present over the entire country. The low diversity in Great Britain and Ireland is therefore likely to be because only species with a tolerance of cold conditions or exceptional dispersal capabilities are present. A DNA 
study in Ireland by Hänfling et al. (2009) found that the Irish endemic, Niphargus kochianus irlandicus, diverged from Niphargus kochianus kochianus from England more than 20 million years ago, suggesting that Niphargus kochianus irlandicus has survived multiple glaciations in refugia.

Habitat continuity is also important in determining large to medium-scale patterns in species distributions, and yet this has not been well investigated. Groundwater catchments often do not coincide with topographical catchments. There may therefore be subsurface hydraulic connectivity between adjacent river basins, enabling dispersal. Rocks with low permeability may form geological barriers, preventing dispersal of most species. Adjacent geologies that provide a continuous habitat but with different chemical and/or physical properties may also prevent dispersal of particular species. In England, lower diversity in the north might be explained by the presence of relatively low permeability geologies in the centre of the country inhibiting dispersal. Understanding the hydrogeological characteristics of faults may also be important to dispersal studies. Faults are planes of movement within rock which occur over scales ranging from $\mathrm{cm}$ to hundreds or even thousands of kilometres. There are many different types, and some create vertical or horizontal voids which may enable groundwater flow. However, where faults are infilled with low permeability material they can form barriers to groundwater flow which results in aquifers that are compartmentalised and divided up into isolated blocks.

Subsurface ecosystems are generally dominated by low dispersal and high numbers of limited-range endemics because geological habitats lack continuity over large areas. Geological studies to determine subsurface dispersal corridors and barriers, or to identify the extent of continuous habitats, might be a useful addition to studies of faunal distributions in groundwaters.

\subsubsection{Aquifer type}

Species may be restricted to specific types of aquifer. Studies have assigned rocks to four hydrogeological categories: compact aquitards (with a low level of fracturing), and porous, fractured and karstic aquifers (e.g. Gibert et al., 1994; Hahn, 2009; Hahn and Fuchs, 2009). The classification is based on the physical characteristics of the rock (void type and connectivity), discussed in section 2.1 .

There is some evidence for differences in species composition among aquifer types, although there has been little sampling in fractured aquifers. In a German study, Hahn and Fuchs (2009) found that the faunal composition of karst, porous, fractured and compact rocks was different although there were similarities between karst and porous aquifers. Analysing data from the European PASCALIS study, Malard et al. (2009) found differences in species composition between karst and porous aquifers.

There are generally more species in karst and porous aquifers than in fractured aquifers and compact aquitards (e.g. Hahn and Fuchs, 2009). Hahn and Fuchs (2009) found that abundance and taxonomic richness per sample was lower in karst aquifers than porous aquifers. In the PASCALIS study species richness in karst and porous aquifers was similar, with 258 species in karst aquifers and 239 in porous aquifers, with an important proportion of species that were exclusive to either karst or porous aquifers (Dole-Olivier et al., 2009a). Malard et al. (2009) analysed the PASCALIS data, together with data from three other 
regions in France, and found that there were more species in porous than in karstic aquifers, suggesting that the additional French data included many species from porous aquifers.

Differences in the physical structure of voids in different rock types might affect species distributions. Larger species might be excluded from fractured aquifers or aquitards where there are insufficient networks of larger voids. Alternatively, a species may be restricted to a particular feeding mechanism within a particular void type. It is difficult to determine whether differences in faunal communities in different aquifer types relate more to the physical structure of the aquifer or to the water chemistry. This is because different rock types have distinctive physical and distinctive chemical characteristics. Carbonate aquifers have alkaline waters whilst other types of rocks have more acidic waters. Higher permeability rocks are likely to have higher concentrations of dissolved organic matter, oxygen and nutrients than lower permeability rocks.

In a Belgian study, most species were found in highly permeable geologies with alkaline waters, with some other groups of species in areas of low permeability and low calcium concentrations (Martin et al., 2009). Hahn and Matzke (2005) compared a sandstone area (in which groundwaters had low electrical conductance, low $\mathrm{pH}$, low nitrate and high dissolved oxygen) with an alluvial aquifer (in which groundwaters had higher $\mathrm{pH}$ and electrical conductance, high nitrate and lower dissolved oxygen). All samples from the alluvial aquifer contained fauna but many from the sandstone area did not. In both these studies it is unclear whether the differences in the physical structure (the void type and size) or groundwater chemistry of these aquifers caused the differences in ecology. However, it is probable that a major reason for differences in the ecology of different aquifer types is variability in water chemistry. Studies have demonstrated that species can inhabit different types of voids. For example, Griebler et al. (2010) found little difference in faunal composition of alluvial and karst aquifers in Southern Germany. Water chemistry was also very similar, indicating a high degree of hydrological connectivity between the two aquifers. This implies that these species are not sensitive to changes in void type and can live equally well both in habitats made up of small voids between sand and gravel grains, and in karst habitats comprising fractures and larger solutional voids. Similarly, Dole-Olivier et al. (2009a) reported that in some areas of the PASCALIS study there was no distinction between karst and alluvial aquifers. However, they noted that it was possible that some of the boreholes sampled might have been open to both alluvial deposits and karst limestones, in which case it is not possible to determine the origin of the fauna.

Some species may be more restricted by aquifer type than others. For example, in Southwest England, the endemic amphipod Niphargus glenniei is present in granite and in a highly karstic limestone (Knight, 2008). The alkaline limestones and more acidic granites have very different water chemistry and this species appears to be tolerant of a range of water chemistries and void types.

Further hydrogeological information might help determine how species are constrained by aquifer type more conclusively. It would be useful to include information on the rock types sampled within each category and how rocks are classified into categories. A standard classification system would be useful if different studies are to be combined to determine 
species diversity and richness in different aquifer types, or to determine which species are constrained to particular aquifer types. Hahn (2009) introduced the useful concept of 'georegs', which are geological units within regions. Sampling of georegs enables geological and geographical controls on stygobites to be distinguished. Such studies of specific rock types would be useful to provide a clearer understanding of geological controls on groundwater species. Comparisons between georegs need to be made independently for each type of sample site (spring, borehole, cave, hyporheic zone).

\subsubsection{Local controls on stygobite distributions}

Local physical and chemical variability within aquifers may influence groundwater ecosystems, although this is not easy to investigate because large parts of groundwater habitats are inaccessible, and it is difficult to determine where in aquifers stygobites live. In karst aquifers, different faunal communities have been observed in cave passages, in fissures (Humphreys, 2009), and in the epikarst (Pipan and Culver, 2007). Communities within karst areas may differ due to habitat fragmentation and isolation (Galassi et al. (2009). Similarly, in non-karst aquifers, groundwater ecology may be influenced by local aquifer heterogeneities. In porous aquifers these include variability in compaction or grain size or the presence of preferential flow channels. In fractured aquifers heterogeneity results from variability in fracture distributions and connectivity.

Borehole sampling has indicated that stygobite abundance and diversity decrease with depth (e.g. Strayer, 1994; Mauclaire and Gibert, 2001; Datry et al., 2005; Hancock and Boulton, 2008). Datry et al. (2005) found vertical differences in species composition and a decrease in abundance with depth below the water table in a glaciofluvial aquifer in France. A French study of an alluvial aquifer by Mauclaire and Gibert (2001) found higher taxa richness and total abundance at $1 \mathrm{~m}$ than at $4-5 \mathrm{~m}$ below the water table. It is likely that variability in groundwater fauna with depth is caused by variations in water chemistry with depth because deeper groundwaters tend to have lower oxygen, carbon and nutrient concentrations. However, local aquifer heterogeneity can enable higher concentrations of dissolved oxygen, carbon and nutrients in deeper groundwaters. Targeted sampling to determine where in aquifers stygobites live would improve understanding of stygobite distributions and habitat requirements.

Local variability in dissolved oxygen concentrations is likely to be an important control on groundwater ecosystems. Some groundwater organisms can withstand low oxygen for long periods and stygobites have even been found beneath hydrogen sulphide layers (Humphreys, 2009). Tomlinson and Boulton (2008) report studies that have demonstrated that some groundwater species can tolerate low oxygen levels. These include a study by Danielopol (1989) demonstrating that a groundwater species of amphipod survived two months in hypoxic water, whilst a surface water amphipod species only survived two days. Other studies have shown that groundwater species are able to reduce locomotion and ventilation in hypoxic conditions to reduce their metabolic rate, enabling them to survive (e.g. Malard and Hervant, 1999). However, despite a tolerance of anoxia, dissolved oxygen is widely believed to be a major factor determining the occurrence and distribution of stygobites as they are much more commonly found in groundwaters with high dissolved oxygen concentrations (Strayer, 1994; Tomlinson and Boulton, 2008; Dole-Olivier et al., 2009b; Humphreys, 2009). 
A local supply of organic matter is also important for maintaining groundwater ecosystems. In a study of a glaciofluvial aquifer in France, Datry et al. (2005) demonstrated that dissolved organic carbon was higher in areas of artificial recharge than at control sites, and that this correlated with a greater diversity and abundance of invertebrates. Griebler et al. (2010) also found that species richness and abundance was correlated with the amount of detritus and particulate organic matter.

Strayer (1994) suggests that many groundwater organisms may not be sensitive to changes in water temperature and Gibert et al. (2009) concluded that temperature was not a major factor affecting species diversity in the PASCALIS study areas. Stygobites exist in aquifers over long periods of geological time, during which a wide range of climatic conditions occur resulting in variable groundwater temperatures, suggesting that many species may not be sensitive to temperature.

The impact of variability in nutrient concentrations on groundwater ecosystems is not fully understood. Robertson et al. (2009) note that nutrient enrichment of groundwaters may lead to an abundance of organisms due to an increase in trophic resources (Wood et al. 2008), but can also lead to a reduction in groundwater biodiversity (Wood et al., 2002). Responses to nutrient pollution are likely to be taxon-specific (Scarsbrook and Fenwick 2003; Tomlinson and Boulton, 2008; Hartland et al., 2011). Scarsbrook and Fenwick (2003) found no syncarids in groundwater beneath a sewage bed in New Zealand, suggesting that syncarids may be sensitive to high levels of nutrients, although it is not clear that their absence was definitely due to the sewage. Hartland et al. (2011) found that organic pollution at this site resulted in an increase in Oligochaeta and Amphipoda but Ostracoda were absent. Humphreys (2009) reports a study of ostracods in Australia by Reeves et al. (2007) which found that water with low $\mathrm{pH}$, low Eh indicating a reducing environment, or total nitrogen in excess of $10 \mathrm{mg} \mathrm{L}^{-1}$ rarely contained ostracods, suggesting that they are sensitive to these environmental variables. Dumas and Lescher-Moutoue (2001) found that cyclopoids in a French aquifer appeared not to be affected by high nitrate concentrations. Galassi et al. (2009) thought that phosphate was not important at the Italian PASCALIS sites, but that there was a weak relationship between nitrate and stygobite species.

The chemical controls on groundwater fauna are not fully resolved. This may be due to the variability in water chemistry requirements for different species and the local variability in water chemistry within aquifers. An improved understanding of local spatial variability in groundwater chemistry in the vicinity of sampling sites might enable a better understanding of the water chemistry requirements of particular species, and how water chemistry determines overall diversity distributions.

\subsection{Sampling groundwater for stygobites}

\subsubsection{The hydrogeology of the sample site}

The objective of many groundwater ecology studies is to assess biodiversity and to detect as many species as possible. Sampling is generally done using a net or a trap although in boreholes and the hyporheic zone samples can also be obtained by pumping water and passing this through a net to collect specimens. Sampling can be timed to increase the 
likelihood of capturing diversity. For example, Dole-Olivier et al. (2009a) suggest more stygobites are collected in springs during rising water levels, and in the hyporheic zone during low flow. The correlation between the number of species found and the number of sites sampled reflects the high degree of endemism (e.g; Deharveng et al., 2009; Eberhard et al., 2009; Hahn and Fuchs, 2009), and highlights the need for extensive surveys to capture biodiversity.

Samples may be taken from sediments in the hyporheic zone of rivers, from springs, boreholes, or from streams, pools, and drips in caves. However, these sampling sites represent only a very small part of the groundwater bodies in which fauna live. Understanding groundwater ecosystems therefore requires relating ecological observations at sample sites to local and regional patterns within aquifers in order to understand how the sample site might relate to the wider aquifer setting. Hydrogeologists have a key role to play in this process at all types of sampling sites.

Classical hydrogeology is perhaps least important for studies of the hyporheic zone, which is a transitional environment between surface water and groundwater (Robertson and Wood, 2010). Specialist knowledge of hyporheic hydrology may be required to determine processes and functions. However, hydrogeologists can contribute knowledge of the nature of groundwater inputs to the hyporheic zone and use hydrogeological techniques to determine properties such as permeability and flow rate.

Spring waters contain distinctive ecological communities and there is potential for hydrogeological input to establish how the hydrogeological characteristics of springs influence their ecology. Hydrogeologists investigating groundwater flow and contaminant attenuation processes determine factors such as the source of water in springs, the size and location of the spring catchment area, the nature of groundwater flow feeding the spring (through pore spaces, fractures, fissures, conduits or caves), the chemistry of the spring water, and how water chemistry and flow rates vary through time (e.g. Massei et al., 2006; Toran et al., 2007). Integrating these types of data would enable ecological sampling of springs to be related to the wider aquifer setting.

Hydrogeological input would also be useful in the interpretation of ecological data from cave sites. Karst hydrogeology includes studies of groundwater flow processes, interactions between fissures and conduits, sources of water in cave streams, temporal variations in flows, and understanding fissure distributions. These may all influence the aquatic ecology of caves because they determine the chemistry and the connectivity of water bodies within karst systems. More thorough integration of such studies with ecological studies might provide better constraints on the location and extent of cave habitats.

Hydrogeologists perhaps have the most important role to play in ecological studies of aquifers away from caves, springs and the hyporheic zone, where boreholes are the only means of investigating groundwater. Understanding how ecological communities observed in boreholes relate to those in aquifers requires a full understanding of the hydrogeology in the vicinity of the borehole, and the hydrological functioning of the borehole itself, and these issues are discussed below.

\subsubsection{Sampling stygobites in aquifers using boreholes}


For hydrogeologists boreholes provide access into aquifers enabling direct sampling of groundwaters. Various geophysical, imaging, logging and permeability testing techniques provide information on how geology, fracture density and aquifer properties vary with depth. Boreholes have become an important tool for faunal sampling, and are a good method of investigating biodiversity because fauna may be more highly concentrated in boreholes than aquifers (section 4.2.3).

Several studies have considered how best to capture groundwater biodiversity using boreholes. Eberhard et al. (2009) sampled 424 boreholes in alluvial and fractured aquifers in northwest Australia. They found that one net haul collected $33 \%$ of species, whilst 6 net hauls collected $82 \%$. Hancock and Boulton (2009) sampled boreholes in alluvial aquifers in southeast Australia. They report that 10 net hauls collected on average $64 \%$ of the taxa and $44 \%$ of the total abundance, and when combined with 100 litres from pumping the totals rose to $92.5 \%$ and $74.5 \%$ respectively. Hancock and Boulton (2009) concluded that one off sampling does not sufficiently estimate taxa richness or community composition at their study sites, and suggested that survey periods extending beyond a year may be needed to assess biodiversity. The study of Hancock and Boulton (2009) concluded that pumping was better than net sampling. However, an Australian study by Allford et al. (2008) concluded that net hauling was a more efficient means of detecting groundwater fauna than pumping because in their study pumping did not capture more species than net hauling. They compared results from 55 boreholes in a calcrete aquifer in Western Australia using 3 different methods: nets, pumping and a discrete interval sampler. They concluded that species diversity variations were due to factors other than the sampling method used. They found that 10 net hauls captured all the fauna present in a borehole with a decline in capture rates of more common species in subsequent hauls, but that rare taxa needed up to seven hauls before they were detected.

There are a number of biases that need to be considered when comparing results from different boreholes (Tomlinson et al. 2007). Boreholes may have different diameters and different saturated lengths, and in fractured or karstic aquifers may intercept different numbers of fractures. Some boreholes may be open to a long section of strata (many tens of metres), which may include many fractures or many different habitats in a porous aquifer, or even multiple aquifers. Other boreholes may only be open to a short section of an aquifer. Boreholes may have slotted casing to prevent collapse, and the slot size will influence which species are present. Boreholes penetrate a range of strata, and net hauling or pumping provides no information on the depth at which the stygobites lived within the strata before the borehole was constructed. Without detailed geological and hydrogeological borehole logs it may not be possible to determine which part of an aquifer has been sampled (or even which rock type has been sampled). Borehole seals between aquifers can be poorly constructed and can leak, introducing connectivity between aquifers.

Results from boreholes may also be affected by the season in which sampling is carried out. In some aquifers, especially in karst, there may be seasonal variations in nutrients, carbon and oxygen. There may also be large water table fluctuations which might result in dewatering of fractures or regions of a porous aquifer that stygobites inhabit. Some groundwater systems have a delay of several months in their seasonal response. In these cases investigations of seasonal variability need to sample at low and high water table, rather than during the summer and winter seasons. There have been few studies of 
seasonal variability in stygobite diversity or abundance. In Western Australia, Eberhard et al. (2009) did not find a significant change in species composition or abundance at individual sites with season. Hancock and Boulton (2009) found that in Eastern Australia more species were present in summer than winter, with densities in autumn and spring more like summer than winter.

Many ecological studies undertake water chemistry and faunal sampling concurrently. It is difficult to sample water chemistry in boreholes because there may be substantial variability in the chemistry of the water column. This is particularly common in fractured or karstic aquifers where boreholes intercept fractures with different hydraulic head leading to vertical flows within the borehole (Elci et al., 2001; Maurice et al., 2011). Stygobite distributions within boreholes may be locally determined by vertical variations in water chemistry. Any type of pumped or mixed sample extracted for analysis may therefore not reflect the chemistry of the water in which the groundwater community is living. The bottoms of boreholes often have less flow than higher sections, particularly in fractured or karstic aquifers where there may be several metres at the base where no fractures are intercepted (Maurice et al., 2011). It is therefore possible that water in the bottom of the borehole where many groundwater animals may live could be different to that of the surrounding aquifer water. The complexities of sampling water chemistry and stygobites in boreholes in fractured or karstic aquifers are illustrated in Fig. 4. This schematically shows an inflowing fracture of high hydraulic head $(A)$, which induces upward vertical flow to fracture $B$ which has lower hydraulic head. Higher up, the borehole intersects another fracture (C), which has higher hydraulic head than $B$, thereby inducing downwards vertical flow to fracture $B$. Water in the borehole between $C$ and $B$ originated from fracture $C$, whilst that between fracture $B$ and $A$ originated from fracture $A$. Below fracture $A$ the water has a long residence time in the borehole because there are no fractures and the chemistry is determined by diffuse flow. Stygobites which may have originated from fractures A, B or C may preferentially live at the bottom of the borehole where sediment and organic matter accumulate, or may be present in the water column. The local microhabitats used by stygobites have not been well investigated - either in terms of where in the aquifer stygobites live or how they use microhabitats in boreholes.

\section{$\underline{4.3}$ Estimating stygobite abundance in groundwater}

The significance of stygobites within biogeochemical cycles depends not only on their species richness, but also on their abundance and biomass, and on species interactions (Boulton et al., 2008). Despite this there have been very few estimates of numbers of stygobites or their biomass, and few quantitative estimates of their functional role. Rough calculations by Fenwick et al. (2004), reported in Boulton et al. (2008) indicated that isopod populations investigated in a New Zealand site polluted by effluent process 7 to 28 tonnes of sediment ha ${ }^{-1} \mathrm{y}^{-1}$. Pacioglu (2009) reports a hyporheic zone study in Germany (Gibert et al., 1994 ) in which invertebrates consumed less than $5 \%$ of oxygen in the sediment and had low abundance, suggesting a fairly small contribution to hyporheic respiration. Datry et al. (2005) studied 24 boreholes in France. They report average numbers of invertebrate specimens as 44 per $L$ of pumped water (including epigean as well as hypogean species). 
Figure 4: Schematic of a borehole intercepting three fractures. Arrows indicate flow directions and different shading patterns indicate the three areas within the borehole which have different water chemistry. Stygobites are concentrated at the bottom but may also occur in the water column.

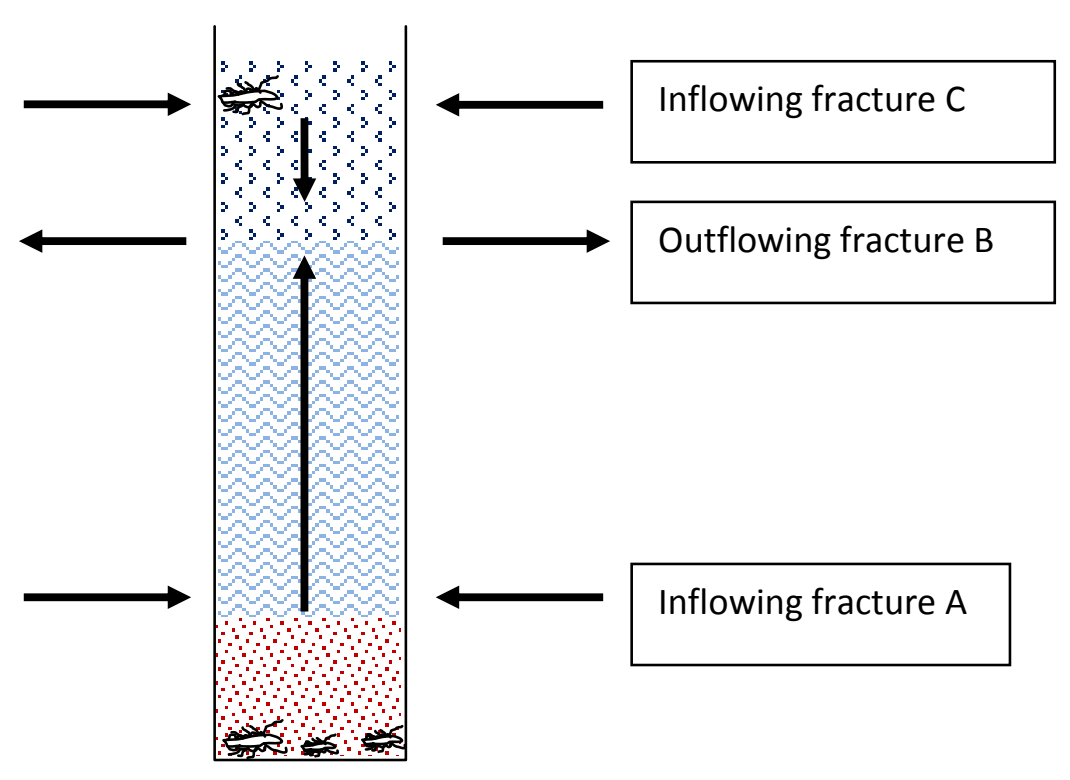

Estimating stygobite abundance is difficult because of the practical problems of counting numbers at sample sites, and the uncertainties in upscaling to abundance in aquifers, caves, springs or the hyporheic zone. It is perhaps easiest in the hyporheic zone, where numbers can be counted per litre of water pumped. This method enables localised sampling which can be repeated at different times or locations to assess temporal and spatial variability in numbers (e.g. Boulton et al., 2003; Stubbington et al., 2009).

There are different options for estimating stygobite numbers in springs. If a spring has a distinct outlet channel where the discharge can be measured it may be possible to make a quantitative estimate by using a drift net across the entire channel and counting invertebrates caught per litre of water passing through the net. However, this would only catch the invertebrates being washed out of the aquifer, and those inhabiting the subsurface spring environment would be missed. A better alternative might be to pump samples from sediments in the vicinity of an upwelling and count the number of individuals per litre using the same method as that used in the hyporheic zone. This might be useful for comparing the numbers of stygobites per litre sampled in different springs, but the total abundance in springs is difficult to determine when the spatial extent of the spring habitat is unknown.

In caves, numbers can be counted in pools or in kick samples, or projected using markrecapture methods (e.g. Knapp and Fong, 1999). However, it may be difficult to upscale to overall abundance in a cave system because of the wide range of habitats, local variability in the numbers of stygobites in pools or streams, and the inaccessibility of many areas.

Estimating faunal abundance from borehole studies is difficult because the relationship between the numbers of stygobites found in a borehole and the numbers present in the aquifer are unknown. It is thought that there may be higher densities of stygobites within 
boreholes than in the surrounding aquifer (Hahn and Matzke, 2005; Tomlinson et al., 2007). This is likely because sediment and detritus collect and are present in greater quantities in boreholes than in the surrounding aquifer, providing a good habitat for stygobites (Hahn and Matzke, 2005). Hahn and Matzke (2005) compared fauna from inside and outside 20 boreholes in fissured sandstone or alluvial material in southwest Germany. The inside of boreholes was sampled by taking $4 \mathrm{~L}$ of water from the bottom. To sample groundwater surrounding the borehole, a section of the borehole was isolated and sealed using two inflatable packers. A piston pump in between the packers was used to take 51 litres of water, pumping at a rate of 3-4 litres per minute. The authors suggested that abundances of fauna were higher inside the borehole. Taxonomic compositions were similar except for nematodes and amphipods which were more common in the samples from the bottom of the boreholes. Investigating stygobites in aquifers using borehole packers is interesting but problematic because there may be stygobites living within the water column in the borehole within the interval isolated by the packers. Unless there is certainty that water within the isolated section and any stygobites living within it are fully purged before the target sample is collected, it is difficult to determine whether stygobites that are collected from within the sealed interval originated from the borehole or the aquifer.

If boreholes support a substantially greater density of fauna than the surrounding aquifer, the total number of species and individuals captured on subsequent sampling occasions might decrease. In the study by Hahn and Matzke (2005) repeated sampling one month later revealed similar abundances and diversities to the initial sampling. Other studies have found that the cumulative number of species recorded increases with the number of sampling occasions (e.g. Eberhard et al., 2009; Hancock and Boulton, 2009). These results could be interpreted as suggesting that the initial sampling only captures a small proportion of the fauna present in the boreholes. Alternatively, they could be interpreted as indicating that new individuals have entered the boreholes between sampling occasions. This would suggest that even though boreholes may have higher numbers of stygobites than the surrounding aquifer, the numbers of animals entering the borehole from the aquifer may be relatively high.

Carefully designed ecological sampling of borehole intervals sealed by packers, using hydrogeological logging and borehole imaging to identify permeable horizons, might determine where in aquifers stygobites live, but sufficient water would need to be pumped from each interval to ensure that aquifer water is sampled.

\section{$\underline{5 \text { Conclusions and areas of future research }}$}

Stygobitic invertebrates provide an important contribution to global biodiversity and a range of ecosystem services. They have high scientific value with a role to play in many diverse areas of science. As some of the oldest ecosystems on Earth, they can inform about past geological and climate changes and the ability of species to survive and adapt to environmental change. Only a small proportion of stygobite biodiversity is known, and many unexplored or partially investigated areas of the world are likely to contain new species.

The study of stygobites is highly interdisciplinary, requiring knowledge of ecology, biology, hydrogeology and geology. Despite this, stygobite studies are often carried out without input from hydrogeologists. Closer collaboration between ecologists and hydrogeologists would be beneficial to both disciplines. Ecologists could gain greater insight into the 
hydrogeological and geological processes determining stygobite distributions. Hydrogeologists could gain an improved understanding of aquifer connectivity and biogeochemical cycles; and the use of stygobites as bioindicators could aid hydrogeological investigations of groundwater quality.

We conclude by suggesting four areas in which future interdisciplinary studies may be particularly interesting: (1) Developing novel methods of estimating invertebrate abundance and biomass to enable more quantitative estimates of ecosystem services. (2) Using hydrogeological data and sampling techniques to determine where in aquifers stygobites live, and how they use microhabitats in boreholes. (3) Using geological and hydrogeological data to establish the location of dispersal corridors and barriers, and to develop conceptual models of the location and extent of the three-dimensional habitat available for a particular species or community. (4) Using high-resolution DNA analysis of stygobites to characterise aquifers, perhaps developing genetic data as a tool for determining catchment areas and hydraulic connectivity between aquifers or areas of aquifers.

\section{Acknowledgements.}

The authors thank two anonymous reviews for their extremely helpful comments.

\section{References}

Allford, A.S. Cooper, J. B. Humphreys, W. F. \& Austin, A. D. (2008). Diversity and distribution of groundwater fauna in a calcrete aquifer: does sampling method influence the story? Invertebrate Systematics 22(2), 127-138.

Arietti, M. \& Edwards, B. (2006). Groundwater invertebrates in chalk boreholes and their significance in public water supply. Internal report for Three Valleys Water. $40 \mathrm{pp}$.

Arnscheidt. J., Hahn, H.J. \& Fuchs, A. (2009). Aquatic subterranean Crustacea in Ireland: results and new records from a pilot study. Cave and Karst Science 35 (1-2), 53-58

Bjarni, K., Kistjánsson, B.K. \& Svavarsson, J. (2007). Subglacial refugia in Iceland enabled groundwater amphipods to survive glaciations. American Naturalist 170, 292-296.

Bork, J., Berkhoff, S. E., Bork, S. \& Hahn, H.J. (2009). Using subsurface metazoan fauna to indicate groundwater-surface water interactions in the Nakdong River floodplain, South Korea. Hydrogeology Journal 17(1), 61-75.

Botosaneanu, L. (ed) (1986). Stygofauna mundi. EJ Brill/Dr W Backhuys, Leiden. 740 pp.

Boulton, A. J., Dole-Olivier M. J. \& Marmonier, P. (2003). Optimizing a sampling strategy for assessing hyporheic invertebrate biodiversity using the Bou-Rouch method: withinsite replication and sample volume. Archiv für Hydrobiologie 156, 431-456.

Boulton, A. J., Fenwick, G.D., Hancock, P.J. \& Harvey, M.S. (2008). Biodiversity, functional roles and ecosystem services of groundwater invertebrates. Invertebrate Systematics 22 (2), 103-116.

Boutin, C. (1994a). Phylogeny and biogeography of metacrangonctid amphipods in North Africa. Hydrobiologia 287 (1), 49-64.

Boutin, C. (1994b). Stygobiology and historical geology - the age of Fuerteventura (Canary Island), as inferred from its present stygofauna. Bulletin de la Societé Geologique de France 165(3), 273-285. 
Bradford, T., Adams, M., Humphreys, W.F., Austin, A.D. \& Cooper, S.J.B. (2010). DNA barcoding of stygofauna uncovers cryptic amphipod diversity in a calcrete aquifer in Western Australia's arid zone. Molecular Ecology Resources 10 (1), 41-50.

Culver, D.C., Pipan, T. \& Schneider, K. (2009). Vicariance, dispersal and scale in the aquatic subterranean fauna of karst regions. Freshwater Biology 54(4), 918-929.

Danielopol, D.L. (1989). Groundwater fauna associated with riverine aquifers. Journal of the North American Benthological Society 8, 18-35.

Danielopol, D. L. \& Griebler, C. (2008). Changing paradigms in groundwater ecology - from the 'living fossils' tradition to the 'new groundwater ecology'. International Review of Hydrobiology 93 (4-5), 565-577.

Danielopol, D. L., Pospisil, P. \& Rouch, R. (2000). Biodiversity in groundwater: a large-scale view. Trends in Ecology \& Evolution 15(6), 223-224.

Datry, T., Malard, F. \& Gibert, J. (2005). Response of invertebrate assemblages to increased groundwater recharge rates in a phreatic aquifer. Journal of the North American Benthological Society 24 (3), 461-477.

Deharveng, L., Stoch, F., Gibert, J., Bedos, A., Galassi, D., Zagmajster, M., Brancelj, A., Camacho, A., Fiers, F., Martin, P., Giani, N., Magniez G. \& Marmonier, P. (2009). Groundwater biodiversity in Europe. Freshwater Biology 54(4), 709-726.

Dole-Olivier, M. J., Castellarini, F., Coineau, N., Galassi, D. M. P., Martin, P., Mori, N., Valdecasas A. \& Gibert, J. (2009a). Towards an optimal sampling strategy to assess groundwater biodiversity: comparison across six European regions. Freshwater Biology 54(4), 777-796.

Dole-Olivier, M. J., Malard, F., Martin, D., Lefébure T. \& Gibert, J. (2009b). Relationships between environmental variables and groundwater biodiversity at the regional scale. Freshwater Biology 54(4), 797-813.

Dole-Olivier, M. J. \& Marmonier, P. (1992). Ecological requirements of stygofauna in an active channel of the Rhone River. Stygologia 7(2), 65-75.

Dumas, P. \& Lescher-Moutoue, F. (2001). Cyclopoid distribution in an agriculturally impacted alluvial aquifer. Archiv für Hydrobiologie 150(3), 511-528.

Eberhard, S. M., Halse, S. A., Williams, M. R., Scanlon, M. D., Cocking J. \& Barron, H. J. (2009). Exploring the relationship between sampling efficiency and short-range endemism for groundwater fauna in the Pilbara region, Western Australia. Freshwater Biology 54(4), 885-901.

Elci, A., Molz, F.J. \& Waldrop, W.R. (2001). Implications of observed and simulated ambient flow in monitoring wells. Ground Water 39 (6), 853-862.

Engel, A.S., Porter, M.L., Stern, L.A., Quinlan, S. \& Bennett, P.C. (2004). Bacterial diversity and ecosystem function of filamentous microbial mats from aphotic (cave) sulfidic springs dominated by chemolithoautotrophic "Epsilonproteobacteria". FEMS Microbiology Ecology 41, 31-53.

Environmental Protection Agency. (2003). Consideration of subterranean fauna in groundwater and caves during Environmental Impact Assessment in Western Australia. Guidance for the Assessment of Environmental Factors (in Accordance with the Environmental Protection Act 1986), No. 54. 12pp.

Fenwick, G.D., Thorpe, H.R. \& White, P.A. (2004). Groundwater systems. In: Freshwaters of New Zealand (eds: J Harding, P. Mosely, C Pearson \& B Sorrell), pp 29.1-29.18. New Zealand Hydrological Society and New Zealand Limnological Society, Christchurch. 
Finston, T.L., Francis, C.J. \& Johnson, M.S. (2009). Biogeography of the stygobitic isopod Pygolabis (Malacostraca: Tainisopidae) in the Pilbara, Western Australia: evidence for multiple colonisations of groundwater. Molecular Phylogenetics and Evolution 52 (2), 448-460.

Flot, J., Wörheide, G. \& Dattagupta, S. (2010). Unsuspected diversity of Niphargus amphipods in the chemoautotrophic cave ecosystem of Frasassi, central Italy. Evolutionary Biology 10, 171.

Foster, S.S.D. (1975). The Chalk groundwater tritium anomaly - a possible explanation. Journal of Hydrology 25, 159-165.

Fretwell, B.A., Burgess, W.G., Barker, J.A. \& Jefferies, N.L. (2005). Redistribution of contaminants by a fluctuating water table in a micro-porous double-porosity aquifer: Field observations and model simulations. Journal of Contaminant Hydrology 78, 2752.

Galassi, D. M. P., Stoch, F., Fiasca, B., Di Lorenzo T. \& Gattone, E. (2009). Groundwater biodiversity patterns in the Lessinian Massif of northern Italy. Freshwater Biology 54(4), 830-847.

Gibert, J. \& Culver, D.C. (2004). Diversity patterns in Europe. In: Encyclopaedia of Caves (eds D.C. Culver \& W.B. White), pp. 196-201. Elsevier/Academic Press, Amsterdam.

Gibert, J. \& Culver, D.C. (2009). Assessing and conserving groundwater biodiversity: an introduction. Freshwater Biology 54(4), 639-648.

Gibert, J. \& Deharveng, L. (2002). Subterranean ecosystems: a truncated functional biodiversity. Bioscience 52, 473-481.

Gibert, J., Culver, D.C., Dole-Olivier, M.J., Malard, F., Christman, M.C. \& Deharveng, L. (2009). Assessing and conserving groundwater biodiversity: synthesis and perspectives. Freshwater Biology 54(4), 930-941.

Gibert, J., Stanford, J.A., Dole-Olivier- M.J. \& Ward, J.V. (1994). Basic attributes of groundwater ecosystems and prospects for research. In: Groundwater Ecology, (eds J. Gibert, D.Danielopol \& J. Stanford), Academic Press Limited, London. pp.7-40.

Griebler, C., Stein, H., Kellermann, C., Berkhoff, S., Brielmann, H., Schmidt, S., Selesi, D., Steube, C., Fuchs, A. \& Hahn, H.J. (2010). Ecological assessment of groundwater ecosystems - vision or illusion? Ecological Engineering 36(9), 1174-1190.

Hahn, H. J. (2006). The GW-Fauna-Index: a first approach to a quantitative ecological assessment of groundwater habitats. Limnologica 36 (2), 119-137.

Hahn, H. J. (2009). A proposal for an extended typology of groundwater habitats. Hydrogeology Journal 17(1), 77-81.

Hahn, H. J. \& Fuchs, A. (2009). Distribution patterns of groundwater communities across aquifer types in south-western Germany. Freshwater Biology 54(4), 848-860.

Hahn, H. J. \& Matzke, D. (2005). A comparison of stygofauna communities inside and outside groundwater bores. Limnologica 35 (1-2), 31-44.

Hallam, F., Yacoubi-Khebiza, M., Oufdou K. \& Boulanouar, M. (2008). Groundwater quality in an arid area of Morocco: impact of pollution on biodiversity and relationships between crustaceans and bacteria of health interest. Environmental Technology 29(11), 1179-1189.

Hancock, P. J. \& Boulton, A. J. (2009). Sampling groundwater fauna: efficiency of rapid assessment methods tested in bores in eastern Australia. Freshwater Biology 54(4), 902-917. 
Hancock, P.J. \& Boulton, A.J. (2008). Stygofauna biodiversity and endemism in four alluvial aquifers in Eastern Australia. Invertebrate Systematics 22 (2), 117-126.

Hancock, P. J., Boulton A. J. \& Humphreys, W. F. (2005). Aquifers and hyporheic zones: towards an ecological understanding of groundwater. Hydrogeology Journal 13(1), 98-111.

Hänfling, B., Douterelo-Soler, I., Knight, L. \& Proudlove, G. (2009). Molecular studies on the Niphargus kochianus group (Crustacea: Amphipoda: Niphargidae) in Great Britain and Ireland. Cave and Karst Science 35 (1-2), 35-40.

Hartland, A., Fenwick, G.D. \& Bury, S.J. (2011). Tracing sewage-derived organic matter into a shallow groundwater food web using stable isotope and fluorescence signatures. Marine and Freshwater Research 62 (2), 119-129.

Humphreys, W.F. (2001). Groundwater calcrete aquifers in the Australian arid zone: the context to an unfolding plethora of stygal biodiversity. Records of the Western Australian Museum: Supplement 64, 63-83.

Humphreys, W. F. (2009). Hydrogeology and groundwater ecology: does each inform the other? Hydrogeology Journal 17(1), 5-21.

Humphreys, W.F., Watts, C.H.S., Cooper, S.J.B. \& Leijs, R. (2009). Groundwater estuaries of salt lakes: buried pools of endemic biodiversity on the western plateau, Australia. Hydrobiologia 626, 79-95.

Hunt, G. W. \& Stanley, E. H. (2000). An evaluation of alternative procedures using the BouRouch method for sampling hyporheic invertebrates. Canadian Journal of Fisheries and Aquatic Sciences 57(8), 1545-1550.

Knapp, S.M. and Fong, D.W., 1999. Estimates of population size of Stygobromus emarginatus (Amphipoda: Crangonyctidea) in a headwater stream in Organ Cave, West Virginia. Journal of Cave and Karst Studies 61 (1) 3-6.

Knight, L.R.F.D. (2008). The Biodiversity Action Plan (BAP) for Niphargus glenniei (Crustacea: Amphipoda: Niphargidae): the first British troglobite to be listed. Cave and Karst Science 35 (1-2), 13-18.

Knight, L.R.F.D. \& Gledhill, T. (2010). The discovery of Microniphargus leruthi Schellenberg, 1934 (Crustacea: Amphipoda: Niphargidae) in Britain and its distribution in the British Isles. Zootaxa, 2655, 52-56.

Korbel, K.L. \& Hose, G.C. (2011). A tiered framework for assessing groundwater ecosystem health. Hydrobiologia 661 (1), 329-349.

Lefébure, T., Douady, C.J., Gouy, M., Trontelj, P., Briolay, J., Gibert, J., 2006. Phylogeography of a subterranean amphipod reveals cryptic diversity and dynamic evolution in extreme environments. Molecular Ecology 15 (7), 1797-1806

Malard, F., Crague, G., Turquin, M., Bouvet, Y. (1994). Monitoring karstic groundwater: the practical aspect of subterranean biology. Theoretical and Applied Karstology 7, 115126

Malard, F. \& Hervant, F. (1999). Oxygen supply and the adaptations of animals in groundwater. Freshwater Biology 41 (1), 1-30.

Malard,F, Plenet, S. \& Gibert, J. (2007). The use of Invertebrates in Groundwater Monitoring: a rising research field. Groundwater Monitoring and Remediation 16 (2), 103-113. 
Malard, F., Boutin, C., Camacho, A.I., Ferreira, D., Michel, G., Sket, B. \& Stoch, F. (2009). Diversity patterns of stygobiotic crustaceans across multiple spatial scales in Europe. Freshwater Biology 54(4), 756-776.

Martin, P., De Broyer, C., Fiers, F., Michel, G., Sablon, R. \& Wouters, K. (2009). Biodiversity of Belgian groundwater fauna in relation to environmental conditions. Freshwater Biology 54(4), 814-829.

Massei, N., Dupont, J.P., Mahler, B.J., Laignel, B.,, Fournier, M., Valdes, D. \& Ogier, S. (2006). Investigating transport properties and turbidity dynamics of a karst aquifer using correlation, spectral, and wavelet analysis. Journal of Hydrology 329 (3-4), 432-443.

Maurice, L., Atkinson, T.C., Williams, A.T., Barker, J.A. \& Farrant, A.R. (2010). Catchment scale tracer testing from karstic features in a porous limestone. Journal of Hydrology 389 (1-2), 31-41.

Maurice, L., Barker, J.A., Atkinson, T.C., Williams, A.T. \& Smart, P.L. (2011). A tracer methodology for identifying flow in and across boreholes. Ground Water 49 (2), 227238

Mauclaire, L. \& Gibert, J. (2001). Environmental determinants of bacterial activity and faunal assemblages in alluvial riverbank aquifers. Archiv für Hydrobiologie 152(3), 469-487.

Mermillod-Blondin, F. \& Rosenberg, R. (2005). Ecosystem engineering: the impact of bioturbation on biogeochemical processes in marine and freshwater benthic habitats. Aquatic Sciences 68 (4), 434-442.

Nogaro, G., Mermillod-Blondin, F., Francois-Carcaillet, F., Gaudet, J.P., Lafont, M. \& Gibert, J. (2006). Invertebrate bioturbation can reduce the clogging of sediment: an experimental study using infiltration sediment columns. Freshwater Biology 51 (8), 1458-1473.

Notenboom, J. (1991). Marine regressions and the evolution of groundwater dwelling amphipods (crustacea). Journal of Biogeography 18(4), 437-454.

NSW Department of Land \& Water Conservation (2002). The NSW state groundwater dependent ecosystems policy. $40 \mathrm{pp}$.

Pacioglu, O. (2009). Ecology of the hyporheic zone: a review. Cave and Karst Science 36(3), 69-76.

Pipan, T. \& Culver, D.C. (2007). Copepod distribution as an indicator of epikarst system connectivity. Hydrogeology Journal 15(4), 817-822.

Porter, M.L., Engel, A.S., Kane, T.C. \& Kinkle, B.K. (2009). Productivity-diversity relationships from chemolithoautotrophically based sulfidic karst systems. International Journal of Speleology 38(1), 27-40.

Proudlove, G.S., Wood, P.J., Harding, P.T., Horne, D.J., Gledhill, T. \& Knight, L.R.F.D. (2003). A review of the status and distribution of the subterranean aquatic Crustacea of Britain and Ireland. Cave and Karst Science 30 (2), 51-74.

Reeves, J. M., De Deckker P. \& Halse, S. A. (2007). Groundwater ostracods from the arid Pilbara region of northwestern Australia: distribution and water chemistry. Hydrobiologia 585 (1), 99-118.

Rivett, M.O., Buss, S.R., Morgan, P., Smith, J.W.N. \& Benment, C. (2008). Nitrate attenuation in groundwater: a review of biogeochemical controlling processes. Water Research 42 (16), 4215-4232.

Robertson, A. L., Smith, J. W. N., Johns, T. \& Proudlove, G.S. (2009). The distribution and diversity of stygobites in Great Britain: an analysis to inform groundwater 
management. Quarterly Journal of Engineering Geology and Hydrogeology 42(3), 359-368.

Robertson, A.L. \& Wood, P.J., 2010. Ecology of the hyporheic zone: origins, current knowledge and future directions. Fundamental and Applied Limnology 176 (4), 279289.

Scarsbrook, M. R. \& Fenwick, G.D. (2003). Preliminary assessment of crustacean distribution patterns in New Zealand groundwater aquifers. New Zealand Journal of Marine and Freshwater Research 37(2), 405-413.

Sket, B. (1999). The nature of biodiversity in hypogean waters and how it is endangered. Biodiversity and Conservation 8, 1319-1338.

Stein, H., Kellermann, C., Schmidt, S. I., Brielmann, H. Steube, C., Berkhoff, S. E., Fuchs, A., Hahn, H. J., Thulin, B. \& Griebler, C. (2010). The potential use of fauna and bacteria as ecological indicators for the assessment of groundwater quality. Journal of Environmental Monitoring 12, 242-254.

Steube, C., Richter, S. \& Griebler, C. (2009). First attempts towards an integrative concept for the ecological assessment of groundwater ecosystems. Hydrogeology Journal 17, 23-35.

Stoch, F. \& Galassi, D.M.P., 2010. Stygobiotic crustacean species richness: a question of numbers, a matter of scale. Hydrobiologia 653 (1), 217-234.

Strayer, D.L. (1994). Limits to biological distributions in groundwater. In: Groundwater Ecology, (eds J. Gibert, D.Danielopol \& J. Stanford), Academic Press Limited, London. pp. 287-310.

Stubbington, R., Wood, P.J. \& Boulton, A.J. (2009). Low flow controls on benthic and macroinvertebrate assemblages during supra-seasonal drought. Hydrological Processes 23, 2252-2263.

Tomlinson, M. \& Boulton, A. (2008). Subsurface Groundwater Dependent Ecosystems: a review of their biodiversity, ecological processes and ecosystem services. Australian Government National Water Commission Report. 77 pp.

Tomlinson, M. \& Boulton, A. (2010). Ecology and Management of subsurface groundwater dependent ecosystems in Australia - a review. Marine and Freshwater Research 61, 936-949.

Tomlinson,M., Boulton, A.J., Hancock, P.J. \& Cook, P.G. (2007) 'Pandora's Box' or unacceptable oversight: should stygofauna surveys be included in groundwater monitoring programs? Hydrogeology Journal. 15 (7), 1317-1320.

Toran, L., Herman, E.K., White, W.B. (2007). Comparison of flowpaths to a well and spring in a karst aquifer. Groundwater 45 (3), 281-287

Trontelj, P., Douady, C. J., Fiser, C., Gibert, J., Goricki, S., Lefébure, T., Sket, B. \& Zaksek, V. (2009). A molecular test for cryptic diversity in ground water: how large are the ranges of macro-stygobionts? Freshwater Biology 54(4), 727-744.

Wood, P. J., Gunn, J. \& Perkins, J. (2002). The impact of pollution on aquatic invertebrates within a subterranean ecosystem - out of site out of mind. Archiv für Hydrobiologie 152, 223-237.

Wood, P. J., Gunn J. \& Rundle, S. D. (2008). Response of benthic cave invertebrates to organic pollution events. Aquatic Conservation-Marine and Freshwater Ecosystems 18(6), 909-922. 